\title{
A liberdade em Locke e Rousseau à luz da teoria de Jurgen Habermas
}

\author{
Emilim Shimamura ${ }^{1}$
}

\begin{abstract}
Resumo
0 presente trabalho teve como preocupação inicial trazer as concepções de liberdade na visão jusnaturalista de John Locke e na construção democrática em Rousseau, o que gera um choque de princípios constitucionais entre liberdade e igualdade. Posteriormente, analisa estas teorias sobre a concepção habermasiana, no qual a liberdade aqui se expressa pela escolha de diferentes tipos de racionalidades para a ação, o que revela uma tensão entre a ação orientada para 0 consenso ou para a instrumentalidade. Com isto, temos a reviravolta habermasiana do conceito de direito, no qual irá propiciar a superação da divergência entre liberdade e igualdade, uma vez que ambas passam coexistir sem contradição.
\end{abstract}

Palavras-Chave: Liberdade; Estado; Direito; Locke; Rousseau; Habermas.

\section{Introdução}

A liberdade é um tema controvertido uma vez que alcança diferentes significações de acordo com a época, autor, e modo de encarar a instituição do Direito e do Estado, implica, deste modo, como são percebidas as relações de poder entre os indivíduos.

0 presente trabalho teve como foco trazer a concepção de liberdade na visão jusnaturalista de John Locke, na construção da democracia libertária em Rousseau para, posteriormente, analisar estas teorias sobre a óptica da liberdade em Habermas, no qual pressupõe a escolha de racionalidades.

Neste sentido, fora necessário traçar os principais aspectos da teoria de Locke e Rousseau, as diferenças conceituais, o contexto histórico em que viviam, e qual a colaboração de ambos para a construção do Estado e do Direito, além de trazer o choque de princípios entre igualdade e liberdade individual.

\footnotetext{
${ }^{1}$ Acadêmica do 40 ano de direito, da Universidade Estadual de Londrina, bolsista PIBIC/CNPq (jul/2007/jul/2008). A autora é aluna o projeto de pesquisa Estado e Relações Empresariais: Diálogos Filosóficos e Jurídicos diante da Regulação Estatal sobre a Ordem Econômica Nacional, e 0 artigo é resultado de pesquisas, aulas expositivas, debates e estudos realizados na segunda fase do projeto, primeiro semestre do ano de 2008.
} 
Fora ainda, de modo sucinto, reconstruído um panorama da evolução histórica do contratualismo, desde Hobbes até a atualidade, para demonstrar a relação entre a formação de um Estado com a sua concepção sobre liberdade.

Em um segundo momento, as principais teorias de Habermas foram tematizadas, como da ação comunicativa e da existência de um direito válido ou fático, pelo qual permite entender que o sujeito passa a ser aquele quem escolhe entre qual tipo de racionalidade utilizar, se instrumental ou comunicativa, ocasionando deste modo, a reviravolta conceitual do direito e da possibilidade da igualdade e liberdade coexistirem sem contradição.

\section{Conceito de liberdade}

De forma ampla, a liberdade segundo José Afonso da Silva (1994, p. 227) “consiste na possibilidade de coordenação consciente dos meios necessários à realização da felicidade pessoal". Na Declaração de 1789 por sua vez, defendia uma liberdade em que era permitido que se fizesse tudo, desde que não prejudicasse a outrem, no qual os direitos naturais de um homem poderiam ser gozados na medida em que outros homens também o pudessem fazêlo, de modo que a lei demarcaria os limites das ações nocivas à sociedade (SILVA, 1994, p. 227), e em uma terceira concepção de liberdade pressupõe que a sociedade esteja pautada na igualdade, uma vez que não se concebe a idéia de sociedade livre constituída por desiguais (KUNTZ, 1997, p.1).

\section{A liberdade e o contrato social}

A Idade Média fora marcada pela dominação da Igreja no campo cultural, econômico e político. Somente na era moderna, período compreendido entre os séculos XVXVIII, com a expansão comercial, o renascimento cultural e científico, os movimentos protestantes, as revoluções burguesas e a substituição de um paradigma pautado na revelação pelo uso da razão, forneceram os elementos para a laicização do Estado (VICENTINO, 1997, p. 111).

A idéia do Estado laico é a separação entre a ordem política e religiosa, e sinaliza um novo modo da sociedade conceber a si mesma, e isto pode ser caracterizado por um processo de transição de uma sociedade marcada pelos dogmas religiosos como meio de 
regular a vida social, por outra forma, própria da modernidade, fundada na idéia de um Contrato Social. Segundo Norberto Bobbio, o contratualismo surgiu como forma de teorizar e fundamentar o poder político é a contraposição entre um estado original, tido como natural por um lado, e por outro, de um espaço de partes sociais unidas, que compactuam em torno de um fim (BOBBIO, 2006, p. 146-155).

Hobbes (1588-1979) construiu um estado fictício de natureza, no qual os homens, a mercê de suas paixões e vícios, viviam em constante estado de guerra, o temor da morte permitiu que, de modo livre e espontâneo, fosse pactuado entre todos a formação de um Estado, a ser governado pelo soberano. Cada indivíduo, ao contratar, depositaria sua liberdade e direitos pessoais na figura do monarca, este detinha deste modo, o monopólio do poder, sendo tal Estado conhecido como Absolutista (TEIXEIRA, 1998, p. 199).

Locke (1632-1704) também foi um contratualista da modernidade, e se opôs ao modelo absolutista idealizando um estado de natureza e um pacto civil no qual se partia do pressuposto de que a natureza humana é livre. Desta constatação, o contrato social surge como meio de garantir que as liberdades individuais venham a ser preservadas, dentre elas, a propriedade é o direito que ganha destaque. A sua teoria influenciou o liberalismo econômico e fez nascer o Estado de Direito (TEIXEIRA, 1998, p. 202-204).

Rousseau (1712-1778) por sua vez, foi um contratualista democrático, seu pensamento girava em torno da participação do povo na política, pois não poderia conceber a idéia de liberdade em que apenas alguns poderiam da lei se beneficiar, portanto 0 sentido que deu à liberdade era de que todos tinham o direito de opinar e definir os rumos da nação. Suas idéias influenciaram a Revolução Francesa de 1789 e construção do Estado Democrático de Direito (SILVA, 1996, p. 9-20).

Atualmente a teoria do contrato social ganha novos contornos diante uma sociedade globalizada e neoliberal, no qual a derrocada do Estado de bem-estar e as forças do mercado vem a questionar se de fato ainda se pode falar em um contrato, uma vez que a idéia de Estado-Nação se fragmenta diante a flexibilização do mercado. Assim, como aponta Simone Goyard Fabre, quando na tematização sobre a teoria habermasiana do direito, a sociedade não se sente representada, formando uma quebra na legitimidade democrática e na própria idéia de um contrato social (FABRE, 2003, p. 317-319). 
Neste sentido, Habermas vem a propor um novo paradigma de direito, no qual há o interesse por parte do autor em teorizar sobre formas que possibilitem o resgate de um contrato democrático. E para tanto, rompe com a tradicional forma de conceber o direito pautado em uma visão jusnaturalista oriunda de Locke e Kant, como também de um paradigma pautado no sujeito e na consciência. Trata-se, na verdade, de trazer a opinião pública para a esfera de poder, mas diferentemente de Rousseau, Habermas mantém a liberdade individual através da possibilidade do sujeito escolher por qual tipo de racionalidade que irá orientar a sua conduta (FABRE, 2003, p. 339-335).

\section{Liberdade em Locke}

John Locke (1632-1704) nasceu na Inglaterra, iluminista, foi um dos precursores das idéias liberais, e dentre as principais obras, destaca-se os Dois Tratados sobre o Governo Civil, que tinha como objetivo negar a ordem absolutista e criar uma teoria capaz de conciliar liberdade com a manutenção da ordem política. No capítulo V, do Segundo Tratado sobre o Governo, Locke irá fundamentar a propriedade como direito natural. Sabe-se, que o Estado de Direito tinha com pressuposto propiciar que as liberdades individuais fossem garantidas, estas eram consideradas frutos da natureza humana, portanto natas e fundamentais, e dentre os direitos individuais que mais de destacam, a propriedade é que ganha relevo, uma vez que através dela é possível a construção de um estado liberal.

Locke partia da idéia de que Deus dera a todos a razão e habilidades físicas, de modo que pudessem utilizá-las para um maior proveito da vida. A terra, os frutos da natureza e animais pertenciam à humanidade em comum, todos poderiam fazer uso, mas existia algo peculiar, o homem era proprietário de si mesmo e por força de seu trabalho, aquilo que foi produzido por suas mãos e inteligência, também em conseqüência passava a Ihe pertencer. Assim, o direito de propriedade é algo natural, o trabalho sobre a coisa, retira o direito de outrem sobre ela (LOCKE, 1973, p. 51-52). Nas palavras de Locke (1973, p. 52) "esta lei da razão torna o veado propriedade do índio que o matou; permite-se que pertençam os bens àquele que thes dedicou o próprio trabalho, embora anteriormente fossem direito comum a todos".

Segundo Rolf Kuntz, este era o estado de natureza de Locke, no qual os sujeitos "vivem em estado de perfeita liberdade para ordenar suas ações e para dispor de suas posses 
e pessoas como julguem adequado, dentro dos limites da lei da natureza, sem pedir autorização ou depender da vontade de qualquer outro homem” (KUNTZ, 2006. p. 5).

Ainda segundo Kuntz, a liberdade em Locke é vista pela ótica da igualdade entre os sujeitos, no sentido de que não há de existir na subordinação de um sobre o outro, como no estado de Hobbes, mas parte da premissa que todos são dotados de inteligência e razão, e estas são as condições de igualdade para que possam usufruir da natureza.

Além disso, a razão humana é capaz de conceber a lei natural de preservação, o que possibilita que todos saibam que não podem destruir um ao outro, ou que a propriedade de cada um deva ser mantida, assim, aquele que violar esta lei natural poderá ser punido, e esta punição também é fruto da lei natural (KUNTZ, 2006. p. 7).

Segundo Locke, o nascimento do dinheiro possibilitou a acumulação de bens, e isto se deve a construção simbólica de determinados bens como sendo de maior valor, tais como o ouro, o diamante e a prata, no qual permitiram que os perecíveis fossem substituídos por metais, de modo que fosse legítima a propriedade por esta não estragar. Nas palavras do autor:

Mediante consenso tácito e voluntário, a maneira de um homem possuir mais terra do que aquela cujo produto pode utilizar, recendendo em troca, pelo excesso, ouro e prata que podem guardar sem causar dano a terceiros, uma vez que estes metais não se deterioram e nem se estragam nas mãos de quem os possui. (LOCKE, 1973, p. 59).

E assim finaliza:

Os homens tornaram praticável semelhante partilha em desigualdade de posses particulares fora dos limites da sociedade sem precisar de pacto, atribuindo valor ao ouro e à prata, e concordando tacitamente com respeito ao uso ao dinheiro; porque, nos governos, as leis regulam o direito de propriedade e constituições positivas determinam a posse da terra. (LOCKE, 1973, p. 59).

Assim, para Locke a propriedade é fruto do trabalho e sua acumulação se justifica pela criação do dinheiro, deste modo, trabalho e propriedade são leis naturais, advinda da razão que devem, ao ser instituído o contrato social, serem reguladas em leis. Segundo Francisco Teixeira (1998, p. 203-204), a invenção do dinheiro e da propriedade acumulada faz nascer conflitos no estado de natureza, e daí a necessidade de ser pactuado o contrato civil, no qual o Estado em Locke é baseado em uma Constituição, com divisão de poderes, 
visando a garantia de direitos individuais e a limitação do poder estatal frente a uma ordem legal.

Estado liberal

Segundo José Afonso da Silva trata-se do Estado de Direito e dentre as principais características destacam-se a obediência de todos conforme os ditames da lei, inclusive do Estado, a existência de poderes divididos em legislativo, executivo e judiciário, e a mais importante delas, a garantia de direitos individuais, configurando a grande conquista da civilização liberal (SILVA, 1994, p. 113-114).

O liberalismo pede a interferência mínima do Estado na vida social e econômica, de modo que o mercado passaria a ser fator de regulação das relações humanas. A liberdade individual, deste modo, atingiria um grau elevado de autonomia, chegando mesmo à idéia de que o indivíduo fosse capaz de criar a sua própria lei. E sendo esta nata, o Estado teria somente a função de preservar a ordem já estabelecida.

Habermas considera que não apenas Locke, mas Kant vem a fundamentar a ordem jurídica de modo liberal, no qual o jusnaturalismo kantiano se caracterizaria pela idéia de um direito pautado na consciência moral individual, pois partiria do pressuposto que a liberdade é produto da razão e, portanto, natural ao homem. Estes dois elementos possibilitariam a realização do imperativo categórico, no qual cada sujeito é capaz se dar a si mesmo a própria lei através da criação de juízos universais do que viria a ser certo ou errado. Para Kant, uma ação somente poderia ser considerada válida se todos também pudessem, nas mesmas condições, agir de igual modo, deste modo, as leis jurídicas e a ordem dada deveriam ser cumpridas, uma vez que nada mais eram que direitos naturais normatizados (DURÃO, 2006, p. 106).

\section{Liberdade em Rousseau}

Segundo Simone Goyard Fabre (2003, p. 153-154), Rousseau teve uma preocupação muito maior com os fundamentos de uma república, do que com a descrição da tipologia dos poderes, tão comum em outros autores. 0 autor vai diferenciar governo de soberania, 
partindo do pressuposto que o fundamento de todo governo é o povo, e não apenas do regime democrático.

Todo pensamento de Rousseau no Contrato Social fora afastar a idéia de uma sociedade fundamentada pelo jusnaturalismo, pois, a idéia de um indivíduo dotado de poder pessoal, com garantias naturais, não era o fundamento do Estado, este deveria ser instituído pela vontade geral do povo, a ser chamada de sociedade civil. E para conceituar a idéia de soberania, faz a distinção desta com o governo. (FABRE, 2003, p. 156).

Segundo 0 filósofo, em Hobbes esta diferenciação não ocorria, de modo que 0 soberano também detinha o governo, propõe deste modo, que soberania fosse sinônimo de vontade geral, e governo um meio de comunicação entre o Soberano e o Estado (FABRE, 2003, p. 157), nas palavras de Fabre (2003, p. 161) o governo é "a instância institucional que tem por vocação subsumir os assuntos particulares ou privados sob a generalidade da regra pública, como tal trabalha pelo equilíbrio das funções e das forças do Estado".

0 governo, portanto, se limitaria a executar a vontade geral do povo, sendo este 0 fundamento da república, ou seja, independentemente do regime adotado, seja monárquico, democrático ou parlamentar, a soberania, na república, é do povo, sua vontade deve sempre preponderar sobre os demais, e o governo é quem executa esta vontade, podendo ser o rei, o primeiro ministro ou o povo.

Assim entendido, Rousseau partia da idéia de não era possível a liberdade sem a existência da igualdade. Segundo o autor, existia dois tipos de desigualdade. Uma advinda da própria natureza, como o peso, a altura e inteligência entre as pessoas, e outra fruto de uma criação e acordo entre os homens. Para eles, esta última era a liberdade liberal, pelo qual admitia que um homem estivesse em condição superior ao outro, e que portanto a liberdade não poderia ser creditada naqueles que estavam em condição inferior (ANDREOLLI, 2003).

A liberdade em Rousseau era positiva, no qual o Estado deveria agir de modo a intervir na vida social, e aquela consistia justamente na possibilidade de todos deliberarem para participar das decisões políticas, o que formaria ao final a vontade geral, se impondo sobre as vontades particulares dos indivíduos (ANDREOLLI, 2003).

Para o autor a democracia deveria ser direta, pois acreditava que a representatividade já instituía a desigualdade e portanto a não liberdade de uns perante a 
liberdade de outros, e portanto idealizava que para sua consecução fosse necessário ser instituída em países pequenos e que a população fosse previamente educada, pois a liberdade, diferentemente dos jusnaturalistas, é fruto de um processo de desenvolvimento do ser em seus aspectos espirituais, cognitivos, morais e físicos. Assim, na obra Emílio, será criado um plano pedagógico pelo autor que visasse o preparo das crianças para viver em um regime democrático.

\section{A construção do caráter e da liberdade humana em Emílio}

Em Emílio, Rousseau idealiza uma personagem no qual está sob os cuidados de seu governante. Estes formam um laço como aluno e mestre e esta relação perdurará para sempre de modo que devam ficar juntos e desenvolver um entendimento mútuo. Acreditava 0 autor, que o homem verdadeiramente livre é aquele que é capaz de desenvolver suas potencialidades para o trabalho, como também seu espírito, e julga que para tanto seja necessário ter próximo de si uma figura exemplar, que atingiu ou está próxima de atingir a sabedoria (ESPÍNDOLA, 2006, p. 229-230).

Para Rousseau, o governante teria que desenvolver para com os governados este papel de mestre e sábio capaz de orientar suas condutas e educar-Ihes conforme os ditames da natureza. Por natureza, entende 0 autor, que esta seria o contado com os próprios sentimentos, para que depois estes orientassem chegar à consciência, ao espírito do ser, uma vez que acreditava existir no mundo uma ordem pré-estabelecida no universo (ESPÍNDOLA, 2006, p. 230-231).

Neste sentido, a educação que o governante deveria adotar era de preocupação central no caráter moral dos indivíduos, pois concebe que a sociedade é eivada de vícios capazes de corromper o coração do homem, e que portanto, as crianças deveriam desde pequenas, serem educadas de modo a fortalecer suas virtudes e liberdade. Acreditava que as crianças deveriam ser mantidas longe da sociedade por um tempo suficiente a permitirem que seus espíritos fossem capazes de não serem corrompidos, e que o processo de amadurecimento nesta etapa deveria ser tratada com especial atenção, no qual passariam por situações que thes exigissem superar os sofrimentos, como o frio no inverno, a sensação de fome, o sofrimento da alma, uma vida com pouco luxo e obstáculos suficientes para 
amadurecer a coragem. Tal processo poderia ser demorado, uma vez que era decisivo estes primeiros anos de vida na vida do cidadão. (ESPÍNDOLA, 2006, p. 231-234).

Assim, para Rousseau a liberdade humana deveria ser construída a base da educação, no qual as crianças aprenderiam a se tornarem sujeitos sadios, fortes, inteligentes, virtuosos e capazes de entrar em contato com seus sentimentos e desejos sem se corromperem diante os vícios sociais. 0 ideal é que ela não se torne vaidosa, com falsa pretensão de ser melhor que os outros e nem vítima, de modo que seja capaz de desenvolver a sabedoria. (ESPÍNDOLA, 2006, p. 234).

Contudo, esta primeira etapa, da infância, o sujeito entrou mais em contato com o aspecto físico da vida, do que com o espírito propriamente dito, apenas com o início da vida adulta que há o despertar de sua racionalidade, para o autor, trata-se tal momento de um segundo nascimento do ser, pois aqui já é capaz de compreender o que real significado do bem. É na adolescência que o homem entraria em contato com as paixões humanas, e estas são essenciais para despertar o sentimento de conservação, e para entrar em contato com a energia espiritual, pelo qual deveria ser utilizada para a construção de algo mais elevado, como o sentimento do amor, amizade e capacidade de criar uma obra, o sujeito no entanto que se deixasse levar pelas paixões de modo desregrado, perderia por sua vez a liberdade (ESPÍNDOLA, 2006, p. 237-240).

\section{Estado democrático de direito}

Segundo José Afonso da Silva, nem sempre a ordem instituída como democrática assim o é, para o autor, a democracia mais que um governo do povo, é um processo, um regime e uma forma de vida (SILVA, 1994, p. 135).

Esta se caracteriza pelo princípio da soberania popular, e nas palavras do autor:

Impõe a participação efetiva e operante do povo na coisa pública, participação que não se exaure, como veremos na simples formação das instituições representativas, que constituem um estágio da evolução do Estado Democrático, mas não são o seu completo desenvolvimento. (SILVA, 1994, p. 118).

Entende desta forma que a participação do povo deva ser efetiva, e a configuração deste regime não significa apenas a tentativa de unir Estado Democrático com Estado de 
Direito, mas a "superação na medida que incorpora um componente revolucionário de transformação do status quo" (SILVA, 1994, p. 119).

Além disso, faz um ressalva importante, não se deve confundir Estado Social de Direito com Democrático, uma vez que o Estado Social, também conhecido como Welfare State, foi um tentativa de "correção do individualismo clássico liberal pela afirmação dos chamados direitos sociais e a realização de objetivos de justiça social" (SILVA, 1994, p. 116). 0 objetivo era conciliar a produção capitalista com políticas de bem-estar social, mas atualmente, este se encontra em declínio, principalmente com a retomada do neoliberalismo.

\section{Liberdade versus igualdade}

Segundo as considerações de Simone Goyard Fabre, no século XIX foram teorizados Estados que se intitulavam democráticos, mas tendiam para direções opostas, como a social democracia e a democracia liberal. Entende, que a democracia liberal pareceu ter triunfado no ocidente e isto se revela na Revolução Francesa (1789) e na Declaração de Independência dos Estados Unidos (1776), no qual, apesar de terem estabelecido princípios como a Liberdade e a Igualdade, não delimitaram, contudo, as suas definições. Isto acarretou em interpretações diversas, mas que guardavam um traço em comum, a liberdade, para a maioria dos liberais democratas, era aquela pautada na lei, na distinção e equilíbrio de poderes, no sistema de representação e na eleição. Apesar de ter instituído, portanto, a democracia, esta não fora no entanto verificada, pois o centro deste regime se situava na proteção à propriedade (FABRE, 2003, p. 225-226).

Tocqueville, teórico liberal, considerava que a Revolução Francesa não fora propriamente uma revolução a instituir o regime democrático, uma vez que a monarquia cairia de qualquer modo, com ou sem ela e que todo processo democrático não ocorreu, mas tratava-se apenas de teoria, muito diferente da prática. Não admitia o autor a idéia de liberdade e igualdade coexistirem no mesmo ordenamento (FABRE, 2003, p. 219-220).

Já por outro lado os defensores da social democracia reconheciam no sufrágio universal a esperança de grandes transformações, principalmente para os trabalhadores. Esta tendência ganha força com a teoria de Marx, no qual defendiam uma ideologia socializante com espírito democrático, contudo, segundo a autora, o marxismo distorceu 0 
conceito de democracia, e o próprio Lênin no século XX a havia repudiado por completo (FABRE, 2003, p. 228-230).

Há ainda uma outra forma de compreender este regime, que segundo 0 site de verbetes da Usp a social democracia pode ser entendida como:

A forma ideológica correspondente ao estágio de desenvolvimento predominantemente intensivo. Sua base material é o nível de reprodução da força de trabalho consideravelmente mais elevado que no estágio extensivo, necessário ao estágio de desenvolvimento intensivo e assegurado pelo Estado de bem-estar (CSABA DEÁK, 2008).

Aqui, tenta-se relacionar com o Estado de bem-estar, mas este como já visto por José Afonso da Silva, é em realidade uma forma que o capitalismo encontrou para se manter diante a crise do liberalismo no início do século XX, pois, a quebra da bolsa de 29 desarticulou todo o sistema produtivo, e os governos encontraram na intervenção e instituição de direitos sociais uma forma de contornar o problema (SILVA, 1994, p. 116).

Para alguns, o fato da Constituição instituir um sistema híbrido, como para Raul Machado Horta, citado por Eros Grau, ocasionou um choque de princípios, com valores e tendências opostas, no qual podem ofuscar transformações reais (HORTA apud GRAU, p. 157).

\section{Liberdade em Habermas}

Analisar Locke e Rousseau sobre uma perspectiva habermasiana consiste em levantar a questão da contradição de um sistema jurídico em instituir uma ordem pautada na liberdade individual, fundamentada no direito natural, e ao mesmo tempo se dizer democrática, no qual pressupõe a existência de uma ordem construída pela maioria.

Antes, contudo, de adentrar neste assunto, é válido fazer algumas considerações sobre Habermas, sua contextualização histórica e os principais aspectos de sua teoria.

\section{Aspectos gerais}

Habermas (1929), é herdeiro da Escola de Frankfurt, no qual fora criada em 1923 na Alemanha, naquela cidade, mas teve de mudar-se por diversas vezes, inclusive de países, devido às perseguições nazistas. A proposta dos autores, que tiveram como principais 
integrantes, Max Horkheimer, Theodor Wiesengrund Adorno, Herber Marcuse e Walter Benjamin, era de construir uma teoria crítica sobre a sociedade, no qual envolvesse diversos conhecimentos afins, como a filosofia, sociologia, história, psicologia entre outros (ASSOUN, 1991, p. 7-77).

Uma das principais críticas que estes autores levantaram, destaca-se a idéia de uma sociedade que se julga racional e científica, mas que ao mesmo tempo tenha sido capaz de criar duas guerras mundiais no mesmo século e colocar a vida da humanidade toda em risco. Para estes autores, trata-se na verdade de uma pseudo racionalidade, mais orientada para busca de poderes econômicos e políticos sem se preocupar com o que de fato foi idealizado pelos modernos como sendo uma sociedade racional, ou seja, justa, livre e igual, pautada na bandeira dos iluministas.

Assim, para estes primeiros frankfurtianos, a sociedade atual desenvolveu um tipo de racionalidade instrumental pelo qual todos os ramos da vida humana estaria invadida por esta forma de agir. Habermas, no entanto, discordará deste posicionamento, uma vez que para ele o projeto da modernidade ainda não se exauriu, está em construção e o que ocorreu na verdade foi uma separação da razão em duas formas de racionalidade, uma pautada no mundo da vida, chamada de razão comunicativa, e outra orientada para fins estratégicos, denominada instrumental.

O problema que se coloca para Habermas não é a instrumentalidade em si, pois esta trouxe suas contribuições para o mundo, como invenções e descobertas tecnológicas, mas a falha fora tentar adaptar este tipo de racionalidade e métodos, próprio da lógica matemática e ciências naturais, a esfera humana, pautada na subjetividade. Assim o que se tentou foi reduzir os juízos morais a juízos de fato, o que é incompatível, pois cada qual possui uma estrutura peculiar (GARCIA, 1999).

Isto se deve porque a razão instrumental carrega como caráter a concepção de que seja possível se chegar a um determinado fim a partir de caminhos logicamente orientados, esta idéia na verdade é ampla e pode envolver desde a positivação em todas as esferas da vida humana, como o uso imposto do método científico como meio de se chegar à verdade e o uso da lógica matemática como esfera de controle e objetividade, até mesmo a possibilidade do uso estratégico da razão, no qual o sujeito age sempre orientado para um determinado fim. 
Deste modo, o que se tem é uma redução gradativa de formas espontâneas de vida, pelo qual Habermas denominou de mundo da vida, para formas logicizadas e estruturalmente determinadas na busca de poder, a que chamou de mundo sistêmico.

Como mundo da vida entendem-se as formas de relação pautada na idéia de consenso, no qual os sujeitos agem de modo solidário uns com outros, sem nada almejarem, utilizando-se da razão comunicativa. Já quando pautados em uma racionalidade estratégica, os sujeitos agem orientados para um fim determinado, no qual o objetivo é alcançar alguma vantagem pessoal.

Para Habermas, o diálogo no mundo da vida ocorrem em dois níveis, primeiro de modo pré-teórico, quando os sujeitos não tematizam uma problemática em si, apenas conversam de modo a deixar que as idéias do senso comum se expressem e qualquer divergência possa ser desfeita com a ação comunicativa, e um segundo nível, quando a validade da norma é questionada, então os sujeitos devem abandonar a ação comunicativa e passam a verbalizar discursos práticos, baseados no consenso e no entendimento (DURÃO, 2006, p. 104).

O conceito do Princípio do Discurso de Habermas, segundo Fernando Vallespín, de modo geral, significa que somente serão consideradas como normas válidas àquelas que são frutos de uma construção por todos os interessados ou atingidos, que se dá mediante a utilização de discursos racionais (VALLESPÍN apud HABERMAS, 1998, p. 29).

Habermas ainda trata da pretensão de validade dos atos de fala, no qual pressupõe um certo tipo de atitude de quem se comunica, assim, nas conversas pertencentes ao mundo da vida, os atos de fala devem estar pautados na retidão, inteligibilidade, sinceridade e serem verdadeiros (DURÃO, 2006, p. 103-104).

\section{Faticidade e validez}

Como visto, Habermas é herdeiro da escola de Frankfurt, como tal, sua teoria também é crítica, e este traço pode ser observado quando propõe um novo conceito de direito desvinculado do paradigma moderno centrado no indivíduo e na consciência (FABRE, 2003, p. 320).

Para Habermas o direito, após a obra Faticidade e Validez, passou a ser visto como um medium integrador entre mundo sistêmico e mundo da vida. Antes contudo, entendia o 
autor, que o direito era um meio pelo qual a razão instrumental utilizava-se para perpetuar as formas de dominação do poder econômico e político. Mas com a reviravolta conceitual, 0 direito passa a ser encarado como uma entidade neutra, pelo qual os sujeitos podem acionálo, de modo, que quem irá optar por uma racionalidade estratégica ou comunicativa é o próprio sujeito que o utiliza (DURÃO, 2006, p. 104-105).

Assim, existiria uma tensão entre a validade e a faticidade de uma ação de acordo com esta opção do sujeito, que poderia se dar em três níveis: na norma jurídica, no sistema de direitos e no estado democrático de direito (DURÃO, 2006, p. 107).

Na norma jurídica ocorre quando, por exemplo, o sujeito se encontra diante uma situação em que irá utilizar a lei. Poderá optar por uma razão estratégica, calculando somente os benefícios ou malefícios de agir de acordo ou não com ela, neste sentido, age-se orientado somente pelos fins, tomando como base de cálculo somente os fatos. Ou seja, o sujeito usa de uma lógica matemática, se isto então aquilo.

Por outro lado, poderá se portar diante a norma e cumpri-la por entender que seu conteúdo é justo, deliberando com os outros sujeitos a cerca de sua validade. Busca-se aqui, a utilização de uma racionalidade própria do ser humano, ou seja, comunicativa, pressupondo que a idéia de verdade não existe, mas que pode aparecer conforme cada um expresse suas razões, o objetivo é compreender o outro, a si e também o contexto das coisas, para se chegar o mais próximo do entendimento, ou consenso. Busca-se, portanto, a validez da norma. (DURÃO, 2006, p. 107).

A tensão, contudo, no segundo nível, ocorrerá no sistema de direitos, no qual, na elaboração da lei, o sujeito, poderá agir conforme uma esfera privada de ação, levando em consideração apenas seus motivos particulares para a instituição da lei e, portanto, agindo de modo estratégico e fático, ou poderá de outro modo, no processo de construção destas normas, optar por uma conduta que vislumbre uma esfera pública de ação, no qual a lei é pensada como algo capaz de atingir toda a coletividade, devendo portanto ser produto de uma deliberação conjunta com todos interessados, a racionalidade deste modo seria comunicativa voltada para a validez (DURÃO, 2006, p. 108).

E no sistema democrático de direito, parte-se da idéia de que o direito é um sistema neutro e integrador do mundo da vida e mundo sistêmico. Portanto, a sua utilização dependerá do tipo de racionalidade escolhida pelo sujeito. A tensão neste nível ocorre, 
quando a sociedade do mundo da vida, que poderia usar dos mecanismos do direito para fazer valer sua vontade, não é capaz de acioná-lo e converter suas necessidades em leis, e isto se dá porque as formas sistêmicas de relação, não permitem que as pessoas pertencentes ao mundo da vida, através de suas técnicas de manipulação de massa, consigam efetivar as normas democráticas já instituídas. A tensão neste caso está entre a formas de pressão social e opinião pública do mundo da vida e a formas sistêmicas na tentativa de manipulá-las (DURÃO, 2006, p. 116).

\section{A liberdade em Locke e Rousseau à luz da teoria de Jurgen Habermas}

Assim visto, retoma-se a discussão inicial, qual seja, da contradição entre a idéia de liberdade proposta por Locke, a individual, e daquela proposta por Rousseau, de igualdade. Segundo Aylton Barbieri Durão, a contradição entre a idéia de um sistema jurídico pautado na defesa de direitos humanos, portando de direitos individuais, e que ao mesmo tempo visa garantir a soberania popular, ou seja, a igualdade entre as pessoas, pode restar superada com a nova conceituação de direito em Habermas.

Tal contradição, nas palavras de Durão, pode ser assim observada:

O liberalismo privilegiou a autonomia privada dos indivíduos, pois os direitos subjetivos representam direitos humanos inalienáveis da pessoa humana e, conseqüentemente, exigem a salvaguarda das liberdades individuais frente às intromissões do estado; isso origina a idéia de império da lei na medida em que os direitos fundamentais da pessoa humana devem ser blindados na constituição contra a possibilidade de alterações promovidas pela arbitrariedade dos governantes ou tirania das maiorias inconseqüentes (DURÃO, 2006, p. 111).

E prossegue na explicação da corrente contrária:

Enquanto o republicanismo, por outro lado, valorizou a autonomia pública, pois considera que, através do exercício da soberania popular, qualquer um que legisle em nome de outro, pode cometer uma injustiça contra ele, mas o povo unido não pode cometer injustiças contra si mesmo, ainda que somente se possa esperar 0 exercício da soberania popular dos cidadãos como um auto-entendimento ético dos valores ancorados na homogeneidade de costumes e na solidariedade espontânea fomentada por leis antigas que também já se tornaram costumes (DURÃO, 2006, p. 111). 
Rousseau considerava que os direitos humanos, que protegiam as liberdades subjetivas dos indivíduos, eram legitimados apenas pela forma gramatical da lei, no qual garantiam um tratamento de igualdade perante a lei, ou seja, apenas formal. Contudo, tal igualdade não era legítima, pois o que tornava o princípio da igualdade ativo era a possibilidade de participar da elaboração da norma, dado que posteriormente eles estariam todos submetidos aos seus ditames. (DURÃO, 2006, p. 112).

Para Durão, esta coexistência de direitos divergentes ocorre desde 0 início da modernidade, sem que ninguém, contudo, viesse a solucionar a questão. E este conflito se revela de modos diferentes, mas com o mesmo caráter, como na Alemanha entre Savigny e Kelsen, na América do Norte entre o liberalismo e o comunitarismo e na filosofia entre Rousseau e Kant. (DURÃO, 2006, p. 110-112).

Em Rousseau foi sintetizado a idéia de soberania popular, em Kant, segundo Habermas, fora sintetizada por sua vez a idéia de autonomia dos direitos humanos, portanto liberais. Apesar de Locke ter sido aquele pelo qual é lembrado como pai do liberalismo político, Habermas apontará a teoria de Kant como liberal, mas uma analogia entre estes pensadores é possível porque o alvo da crítica é o mesmo para os dois, qual seja, o fato de pautarem o direito no jusnaturalismo, pelo qual se tem o fundamento de um direito baseado na natureza, portanto irrefutável. 0 que para Habermas é inconcebível, uma vez que sua teoria parte do pressuposto que uma norma somente poderá ser tida como válida se produto de um consenso, em que todos os interessados possam participar.

No entanto, Habermas também não concorda com Rousseau, por ser a sua teoria, também como a de Kant, produto da consciência, segundo o que, é pautado na idéia de um sujeito moral que institui o direito, no caso de Rousseau, de um sujeito macro, o povo como um todo. Contudo, Habermas irá diferenciar o direito da moral, por cinco motivos: na moral há apenas um caminho, pela maioria ela é válida ou não, enquanto que no direito há a possibilidade de optar por uma ação orientada para fins individuais ou coletivos; na moral os temas dos discursos são mais limitados, e no direito mais amplos; as normas morais tem um discurso mais amplo, pois podem falar sobre o que é universal para toda humanidade e 0 discurso jurídico se restringe ao que esta posto no ordenamento; as normas morais são geradas pelo mundo da vida e o direito por meios artificiais; e por fim, a moral perde espaço 
como meio de regulação social e o direito é meio de integração social, que faculta ao sujeito o uso da razão estratégica ou comunicativa (DURÃO, 2006, p. 114-115).

Deste modo o direito não pode ser produto da moral, mas de formas válidas ou factuais que o instituem. Assim, quando na elaboração do direito, portanto da tensão, já reportada, existente no sistema de direitos, Habermas, conceberá que a liberdade individual e a soberania popular podem coexistir sem contradição, pois, uma vez que o processo de auto-legislação se inicia, ou seja, as normas passam a ser estabelecidas, o sujeito pode optar por uma forma privada de legislar, que vise apenas o benefício próprio, ou escolher por um esfera pública, pelo qual a ação é orientada para a sua validade, que pressupõe o uso do princípio do discurso (DURÃO, 2006, p. 109).

No primeiro caso, se orientado pela racionalidade sistêmica, no qual a esfera privada é tida como prioritária, mantidos estão os direitos individuais, no entanto, se orientado pela racionalidade comunicativa, que leva em conta interesses diversos e uma forma de entendimento recíproco, mantida está a soberania popular. Assim, o sistema de direitos permite que ao mesmo tempo, ocorra a criação de direitos humanos individuais e a formação de direitos políticos, além de manter preservada a liberdade pessoal do indivíduo em optar por qual racionalidade utilizar (DURÃO, 2006, p. 19).

\section{Conclusão}

Por ser o direito entendido como meio integrador entre mundo sistêmico e mundo da vida, e que a opção por qual tipo de racionalidade utilizar, se estratégica ou comunicativa, permitiu que Habermas superasse a antiga contradição de coexistência de direitos humanos, advindos da idéia de um direito jusnaturalista, com a idéia de soberania popular, pautada na vontade popular e no principio da igualdade.

Isto se deve pelo fato de ocorrer uma tensão entre faticidade e validez das ações referentes ao mundo jurídico. Se por um lado, a lei permite que a ação do sujeito seja pautada tão somente em fins privados, ela garante que o direito individual seja preservado, e se possibilita também que a ação seja orientada para o entendimento de todos, pautado no consenso, permite a expressão da soberania popular. 
Deste modo, Habermas irá propor um novo paradigma para o direito, pelo qual remete a uma nova forma de encarar a liberdade, que pode abrir caminhos tanto para a construção de espaços sistêmicos na sociedade, como do mundo da vida.

Além disso, foi possível verificar que Habermas, ainda que de modo indireto, compreende que o modo de pensar as relações sob a ótica instrumental pode estar vinculado a construção do mundo liberal, pelo qual tem como paradigma a fundamentação de um Estado de Direito garantidor da propriedade privada e direitos burgueses.

E que o Estado Democrático estaria ligado a formas mais propensas ao mundo da vida, uma vez que os sujeitos são considerados iguais e podem manter relações menos estratégicas, uma vez que se orientam para o entendimento.

Deste modo, surgiria na sociedade formas diferentes de racionalidades, e estas tenderiam a condicionar o que cada um venha a compreender sobre o que seja liberdade, temos, portanto, em Locke a liberdade pela óptica individual, em Rousseau na idéia de participação igualitária nos rumos políticos e em Habermas a sujeição desta escolha a ser realizada pelos sujeitos de direito.

\section{Referências}

ANDREOLLI, Antonio Inácio. A democracia direta em Rousseau. Revista espaço acadêmico, v. 2, n. 22, mar.2003. Disponível em: বhttp://www.espacoacademico.com.br/022/22and_ rousseau.htm>. Acesso em: 20 jun. 2008.

ASSOUN, Paul Laurent. A escola de frankfurt. São Paulo: Ática, 1991.

CSABA DEÁK. Verbetes de economia política e urbanismo. 2002. Disponível em: বtttp://www.usp.br/fau/docentes/depprojeto/c_deak/CD/4verb/index.html >. Acesso em: 13 jul. 2008.

DURÃO, Aylton Barbieri. A tensão entre faticidade e validade no direito segundo habermas. Revista Eyhica, Florianópolis, v 5, n 1, jun. 2006.

ESPÍNDOLA, Arlei de. Rousseau, Sêneca e a construção da liberdade individual. Revista faz ciência, v. 8, n. 1, 2006. Disponível em:

«biblioteca.universia.net/html_bura/ficha/params/id/ 3972772.html>. Acesso em: 15 jul. 2008.

FABRE, Simone Goyard. 0 que é democracia? São Paulo: M artins Fontes, 2003. 
GARCIA, Bianco Zalmora. A reconceituação habermasiana dos fundamentos da relação teoria e prática. In . A construção do projeto político pedagógico da escola pública na perspectiva da teoria da ação comunicativa de Jurgen Habermas. 1999. Dissertação (mestrado ) - Faculdade de Educação da Universidade de São Paulo, São Paulo, 1999.

GRAU, Eros Roberto. A ordem econômica na constituição de 1988. 9. ed. São Paulo: Malheiros, 2003.

HABERM AS, Jurgen. Debate sobre el liberalismo político. Barcelona: Paidós, 1998.

KUNTZ, Rolf. Locke, liberdade, igualdade e propriedade. Instituto de estudos avançados da Universidade de São Paulo, São Paulo, 1997. Disponível em: «www.iea.usp.br/iea/artigos/ kuntzlocke.pdf>Acesso em: 02 jul. 2008.

LOCKE, John. Segundo tratado sobre o governo: ensaio sobre a verdadeira origem, extensão e objetivo do governo civil. São Paulo: Abril Cultural, 1973.

SILVA, José Afonso. Curso de direito constitucional positivo. 10. ed. São Paulo: M alheiros, 1994.

TEIXEIRA, Francisco José Soares. 0 neoliberalismo em debate. In: TEIXEIRA, Francisco J. S., OLIVERIA, M anfredo A. Neoliberalismo e reestruturação produtiva. 2. ed. São Paulo: Cortez, 1998. 